\title{
ISB NEWS
}

\section{ISB News July 2009}

\section{Paul J. Beggs}

(C) ISB 2009

\section{From the President}

It gives me great pleasure to announce the publication of Biometeorology for Adaptation to Climate Variability and Change by Springer. The Editors of the book, Kristie L. Ebi, Ian Burton, and Glenn R. McGregor, as well as the various authors of the chapters, are to be congratulated on this fine achievement.

Impacts of climate change on natural and human environments have already been observed, and many future impacts on a wide range of systems and sectors are projected. The costs of these impacts will increase over time (IPCC 2007). It is therefore vital that we now respond to climate change through both mitigation and adaptation. Biometeorologists and the International Society of Biometeorology have an important role to perform in all aspects of climate change research, and the publication of this book is an excellent demonstration of this.
Biometeorology for Adaptation to Climate Variability and Change is Volume 1 in a new Biometeorology Series by Springer, with the International Society for Biometeorology's President-Elect, Prof Glenn McGregor, serving as the Series Chief Editor, and other members of the Society making up its Editorial Board. I look forward to future volumes in this series.

Finally, let me take this opportunity to wish all a happy winter or summer solstice (for readers in the Southern and Northern Hemispheres, respectively) on 21 June.

\section{Reference}

IPCC (2007) Summary for policymakers. In: Parry ML, Canziani OF, Palutikof JP, van der Linden PJ, Hanson CE (eds) Climate change 2007: impacts, adaptation and vulnerability. Contribution of Working Group II to the Fourth Assessment Report of the Intergovernmental Panel on Climate Change. Cambridge University Press, Cambridge, UK, pp 7-22
P. J. Beggs ( $ه)$

Department of Environment and Geography,

Macquarie University,

Sydney, Australia

e-mail: paul.beggs@mq.edu.au 